\title{
Effects of terrigenous sedimentation on mangrove physiology and associated macrobenthic communities
}

\author{
J. Ellis ${ }^{1,2, *}$, P. Nicholls ${ }^{1}$, R. Craggs $^{1}$, D. Hofstra ${ }^{1}$, J. Hewitt $^{1}$ \\ ${ }^{1}$ National Institute of Water and Atmospheric Research, PO Box 11-115, Hamilton, New Zealand \\ ${ }^{2}$ Present address: 18 Cabot Street, St John's, Newfoundland A1C 1Z4, Canada
}

\begin{abstract}
In New Zealand, one species of mangrove, Avicennia marina var. australasica, forms a characteristic and often an extensive feature of the tidal mudflats of harbours and estuaries. Within their natural range, mangroves have generally increased in abundance in New Zealand over the last $100 \mathrm{yr}$ in response to increased sedimentation associated with concurrent changes in catchment land use. However, little information is available about the ecological consequences of changes in the extent of mangrove habitats under varying sedimentation regimes. We therefore conducted a study to determine the effects of high sedimentation rates on mangrove plant communities and associated benthic community composition. We selected an estuary that is experiencing high rates of sedimentation (as high as $23 \mathrm{~mm} \mathrm{yr}^{-1}$ ) and associated increases in mangrove area. We recorded clear differences in both plant and benthic communities along a gradient of decreasing sedimentation. Mangrove architecture (such as height and density of plants) and health (as measured by chlorophyll a fluorescence) were linked to high mud content of the sediment and elevated sedimentation patterns. Mangrove plants at the upper landward sites, characterised by a high percentage of mud and high total nutrients (total phosphorus [TP] and total nitrogen [TN]) and organic content, were taller than those at the seaward sites and had a larger number of pneumatophores as well as the greatest number of new seedlings. However, benthic macrofaunal diversity and abundance within the mangrove habitats were lower than expected, and clear functional differences were found between habitats with differing sedimentation patterns. Sites with high sedimentation rates had lower numbers of suspension feeders, low macrobenthic diversity, and were dominated by deposit-feeding polychaetes and oligochaetes. The diversity and density of benthic macrofaunal communities was, however, lower than that of sandflat communities for both mangrove habitats and adjacent intertidal mudflats in these sheltered areas, suggesting a response to the increased silt/clay from sedimentation rather than to the mangroves themselves. Our study demonstrates the potential for functional and structural effects on benthic communities on a larger spatial scale in estuarine areas experiencing high rates of sedimentation.
\end{abstract}

KEY WORDS: Mangrove $\cdot$ Benthic community composition $\cdot$ Sedimentation $\cdot$ Growth $\cdot$ Physiological condition $\cdot$ Estuary $\cdot$ New Zealand

Resale or republication not permitted without written consent of the publisher

\section{INTRODUCTION}

Increases in sediment loads to coastal ecosystems as a result of catchment development have been recognised as a contaminant of considerable importance (GESAMP 1994, Gray 1997). Elevated sediment loading to estuarine and coastal environments can occur via a number of mechanisms, including urban development, and often results in increased turbidity and sedimentation rates in estuarine and coastal waters. Estuaries and tidal inlets are particularly vulnerable to increased levels of sedimentation as they act as natural retention systems. Potentially, this can mean broader-scale changes to coastal and estuarine systems by modification of habitat types (Smith \& Kukert 1996, Saiz-Salini \& Urkiaga-Alberdi 1999), including the spread or loss of vegetated habitats such as mangroves, and by influencing the health, 
abundance and distribution of benthic animals. Sediment depositions affect benthic invertebrates in a number of ways: (1) by physically smothering the sediment surface, causing anoxia; (2) by changing the sediment grain size, effecting rates of faunal movement and the sediment biogeochemistry; (3) by enhancing turbidity, with implications for suspension feeders and primary productivity; and (4) by changing the sediment food quality (Norkko et al. 2002, Cummingset al. 2003). Decreases in the diversity of soft sediment systems following catastrophic sedimentation events (Norkko et al. 2002, Thrush et al. 2003a) and changes in the health and distribution of key suspension feeders due to increased turbidity levels (Ellis et al. 2002) have been documented for New Zealand systems. Further, recovery of soft sediment habitats following sedimentation events has been found to be site dependent with more sheltered areas with reduced flows displaying longer recovery trajectories than more physically dynamic habitats (Norkko et al. 2002).

In New Zealand, these more sheltered areas are often colonised by one species of mangrove, Avicennia marina var. australasica (Walp) J. Everett, formerly var. resinifera, which form a characteristic and often an extensive feature of the tidal mudflats of harbours and estuaries. Mangrove communities are restricted to the upper parts of the North Island of New Zealand (Crisp et al. 1990) and are close to the natural southern limit for mangroves in the world. Within their natural range, mangroves have generally increased in abundance in New Zealand over the last $100 \mathrm{yr}$. The increase in mangrove area has been attributed to increased sedimentation associated with concurrent changes in catchment land use including land clearance, development of plantation forest, intensified farming and increased urbanisation (Burns \& Ogden 1985, de Lange \& de Lange 1994). However, while significant changes in the distribution of mangrove habitats have been documented, little information is available about the ecological consequences of changes in the extent of mangrove habitats under varying sedimentation regimes. Further, benthic faunal communities inhabiting intertidal mangrove substrates and their relative abundances to those in adjacent habitats are poorly known (Sheridan 1997).

To determine the ecological consequences of the spread of mangrove habitats as well as some of the key environmental parameters influencing both mangrove plant health and benthic community composition our study investigated plant and animal responses along a gradient of sedimentation. The scale of the work was sufficiently large to encompass gradients in sedimentation rates and hydrodynamic parameters.

\section{MATERIALS AND METHODS}

Study site. Two estuaries, Mangemangeroa and Waikopua, where the mangrove cover has increased by $50 \%$ or more between 1955 and 2000 (as estimated from aerial photography) were selected. Growing pressure on land use and urban development in the Auckland region is resulting in increased sediment deposition associated with catchment development. Urbanisation of the surrounding Whitford catchment has resulted in significant inputs of sediments to the estuary (A. Swales, T. Hume, J. Oldman, M. Green unpubl. data). While most of the increase in mangrove area has been limited in Mangemangeroa to the upper landward part of the estuary, mangroves at Waikopua have extended their distribution seaward onto unvegetated intertidal flats, with the consequent loss of sandflat habitats.

To determine the physiological responses of mangroves to sedimentation, plant health, plant architecture, sediment characteristics and sedimentation rates were monitored. Plant health was assessed by a chlorophyll a (chl a) fluorescence technique, and plant architecture and sediment characteristics were measured on a monthly basis over the period of study (November 2000 to May 2001). Sampling sites were established down the length of the 2 estuaries in the Whitford embayment in the North Island of New Zealand (Fig. 1). In the Mangemangeroa estuary, 5 mangrove sites (M1, M2, M3, M4 and M5) were established, while in the Waikopua estuary 3 mangrove sites (W1, W2 and W3) were established. At each site, three $0.5 \times 0.5 \mathrm{~m}$ plots were established at $10 \mathrm{~m}$ intervals. The 3 replicate plots were placed parallel to the channel to avoid changes in elevation. Study sites were selected to encompass a broad range of sedimentation rates and biotic factors ranging from high sediment deposition $\left(23.4 \mathrm{~mm} \mathrm{yr}^{-1}\right)$ with sediments comprised of fine muds (82.9\% silt/clay) (Site M5), to sites comprised mainly of fine sands with low silt/clay content (15.3\% silt/clay) and no net accumulation of sediments $\left(\sim 0 \mathrm{~mm} \mathrm{yr}^{-1}\right)$ (Site W1).

Mangrove plant measurements. Plant architecture was determined from variables including tree, sapling, seedling and pneumatophore heights, tree and sapling shoot lengths and stem diameters, and numbers of seedlings and pneumatophores. Saplings were defined as mangroves taller than $0.5 \mathrm{~m}$ but less than $2.5 \mathrm{~cm}$ in stem diameter, with larger plants defined as trees and smaller plants as seedlings. At each site, pneumatophore measurements were made in $0.5 \times 0.5 \mathrm{~m}$ quadrats and included the total number of pneumatophores and the height of 5 randomly selected pneumatophores. Seedling measurements were made in, or as close to, the $0.5 \times 0.5 \mathrm{~m}$ quadrats as possible 


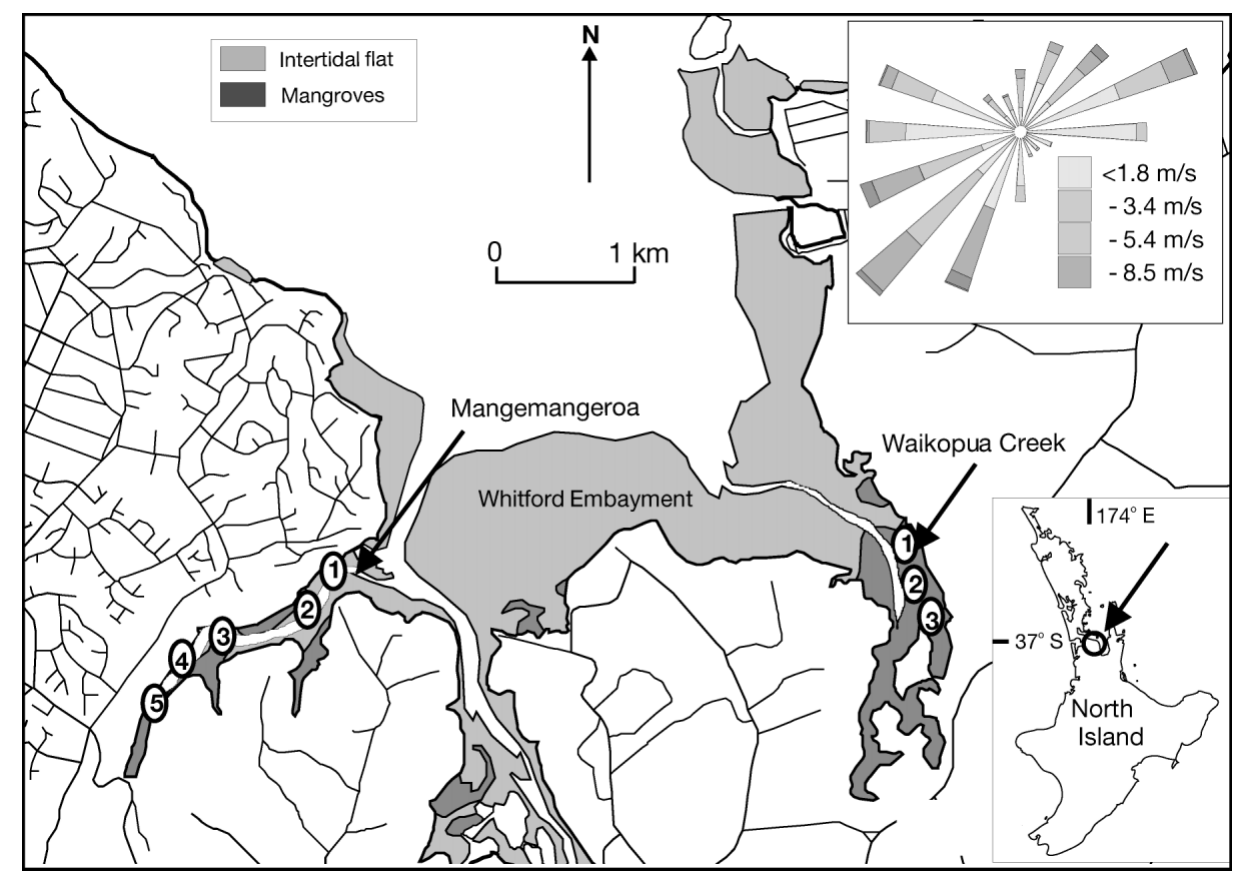

Fig. 1. Whitford embayment and the location of the mangrove study sites in the Mangemangeroa and Waikopua estuaries, North Island, New Zealand. Note the larger fetch towards the Waikopua estuary. Wind rose data are provided in m s${ }^{-1}$

and included the total height of 5 tagged seedlings. At each site, the heights and trunk diameters of 5 randomly selected trees and saplings were also recorded. All measurements were recorded on a monthly basis, except for the tree canopy height and trunk diameters which were recorded in November 2000 and again at the end of the experiment in May 2001.

A portable PAM (pulse amplitude modulated) fluorometer (Diving-PAM, Walz) was used to determine leaf chl a fluorescence as a means of appraising the maximal quantum yield of photosystem II $\left(F_{\mathrm{v}} / F_{\mathrm{m}}\right)$ (Schreiber et al. 1994) of mangrove plants at each study site. The aim was to provide a relative measure of the plants physiological status (Prange \& Dennison 2000) under conditions of full sunlight. $F_{\mathrm{v}} / F_{\mathrm{m}}$ was measured in January and February 2001 on 10 apical leaves exposed to full sunlight. Measurements were made on sunny days between 10:00 and 14:00 h after the leaf had been darkened in a leaf clip for $15 \mathrm{~min}$. At all sites, incident irradiance was $>1600 \mu \mathrm{mol}$ (photons) $\mathrm{m}^{-2} \mathrm{~s}^{-1}$ at the time of measurement. As a reference point, maximum $F_{\mathrm{v}} / F_{\mathrm{m}}$ was also measured at dawn the following morning. The degree to which $F_{\mathrm{v}} / F_{\mathrm{m}}$ measurements during the day were reduced below the dawn maximum was examined in conjunction with plant architecture variables as an indication of a relative degree of photosynthetic stress on one occasion under full sunlight.
Surficial sediment characteristics. At each site, sediment penetrability and cohesiveness were measured in triplicate using a penetrometer and a shearvane, respectively. The penetrometer (with either a 2.5 or $5.0 \mathrm{~cm}$ diameter base) was used to measure the force required to push the base $0.5 \mathrm{~cm}$ into the sediment surface. The shearvane (with either a 4.8 or $9.0 \mathrm{~cm}$ diameter base) was inserted $0.5 \mathrm{~cm}$ into the sediment surface and the force required to move the sediment measured. The measurements recorded from these instruments were converted into $\mathrm{kg} \mathrm{cm}^{-2}$.

Three sediment core samples $(2.0 \mathrm{~cm}$ in diameter, $1.5 \mathrm{~cm}$ deep) were obtained at each site, and subsequently analysed for volatile organic matter (\% VOM), chl $a$, total nutrients (total nitrogen [TN] and total phosphorus [TP]) and grain size. Organic content of the sediment was measured as the weight loss from ignition at $400^{\circ} \mathrm{C}$ for $4.5 \mathrm{~h}$ of samples that had previously been dried until constant (approximately $72 \mathrm{~h}$ ) in a $60^{\circ} \mathrm{C}$ oven (Mook \& Hoskin 1982). Chl a was determined as a measure of food availability for benthic animals, and was extracted from sediments by boiling in $95 \%$ ethanol, and then measured spectrophotometrically. An acidification step was used to separate degradation products from chl a (Sartory 1982). TN was measured as total Kjeldahl nitrogen (g [100 g dry wt $]^{-1}$ ) using a selenium catalyst and Berthelot colorimetry. TP was measured as total recoverable phosphorus ( $\mathrm{mg}[\mathrm{kg}$ 
dry wt $]^{-1}$ ) using inductively coupled plasma-mass spectrometry (ICP-MS) following nitric/hydrochloric acid digestion. Sediment particle size was determined on samples that were predigested $(6 \%$ hydrogen peroxide for $48 \mathrm{~h}$ ) to remove organic matter, and dispersed using Calgon. Subsequently, \% volumes for sediment fractions (gravel, coarse, medium and fine sand, silt and clay) were determined by wet-sieving (particle size $>63 \mu \mathrm{m}$ ). A Galai particle analyser (Galai Cis-100, Galai) was used to measure particle size $<63 \mu \mathrm{m}$ by counting 750000 particles per sample.

Sedimentation rates. Bedload traps were placed at each site to measure the gross amount of sediment deposition over the period of study. Sediment traps were $50 \mathrm{~cm}$ long and were made of stainless steel tubing with an internal diameter of $5 \mathrm{~cm}$ and an aspect ratio of 10:1. Studies of the performance of traps with differing aspect ratios indicate that settled sediment collected in the traps would not be resuspended (Gardner 1980, Butman et al. 1986). Preservatives were not added to the traps on deployment because this can radically alter estimates of sediment organic matter due to the death and decomposition of animals that may swim into the traps (Hedges et al. 1993). The collection efficiency (i.e. whether the material collected in the traps represents what is suspended in the water column) was tested in a previous study (Ellis et al. 2002) and demonstrated that the traps provide a representative sample. Traps were positioned $10 \mathrm{~cm}$ above the intertidal flat and placed at the channel edge of the middle $0.5 \times 0.5 \mathrm{~m}$ plot for each site. Traps were deployed in November 2000 and collected in May 2001. The total amount of sediment was weighed and subsamples of the sediment collected in the traps were analysed for organic content and particle size using the same methods as described above. Sediment traps were selected over other methods of assessing sedimentation rates, such as stakes or erosion pins, because additional information such as potential enrichment effects due to elevated organic loading associated with terrigenous sediments could be evaluated.

Net sedimentation rates over decadal time scales were calculated using standard radioisotope dating techniques determined from sediment cores $(30 \mathrm{~cm}$ long by $10 \mathrm{~cm}$ in diameter) collected at each site. Both peaks in caesium-137 $\left({ }^{137} \mathrm{Cs}\right)$ and lead-210 $\left({ }^{210} \mathrm{~Pb}\right)$ were used for dating sediments (Robbins \& Edgington 1975, Olsen et al. 1981, Ritchie \& McHenry 1989, Valette-Silver 1993, Benoit et al. 1999). Vertical profiles of heavy metals such as $\mathrm{Zn}$ were also used to provide complementary information on sedimentation and in situ mixing processes. Such profiles have been shown to provide useful additional information to identify the onset of urbanisation. Additional cores (7) were also taken at Waikopua that extended seaward onto the intertidal sandflat and landward into the older mangrove stands beyond the monitored sites in order to gain a greater understanding of how sedimentation varies across this vegetated/unvegetated transition zone.

Macrobenthic community composition. To quantify benthic community structure at each site three $13 \mathrm{~cm}$ diameter cores extending $15 \mathrm{~cm}$ into the sediment were taken on a number of sampling occasions to cover temporal variations. Core samples were taken once in December 2000, September 2001 and March 2002. The macrofaunal samples were sieved on a $0.5 \mathrm{~mm}$ mesh, preserved in $70 \%$ isopropyl alcohol and stained with $0.2 \%$ Rose Bengal. Macrofauna retained on the sieves were sorted and identified to the lowest possible level. Photographs were also taken of each mangrove quadrat for rapid quantification of bioturbating infauna density (i.e. number of crab burrows) and other visual sediment characteristics and/or biological variables, such as the presence of epibenthic animals, on the same monthly basis as plant measurements.

Statistical analyses. Multivariate techniques were used to assess differences in plant architecture at each site. A mean for each plant architecture variable (see section 'Mangrove plant measurements') at each site was derived. The analysis also included percentage growth (height and diameter) for tree, sapling,

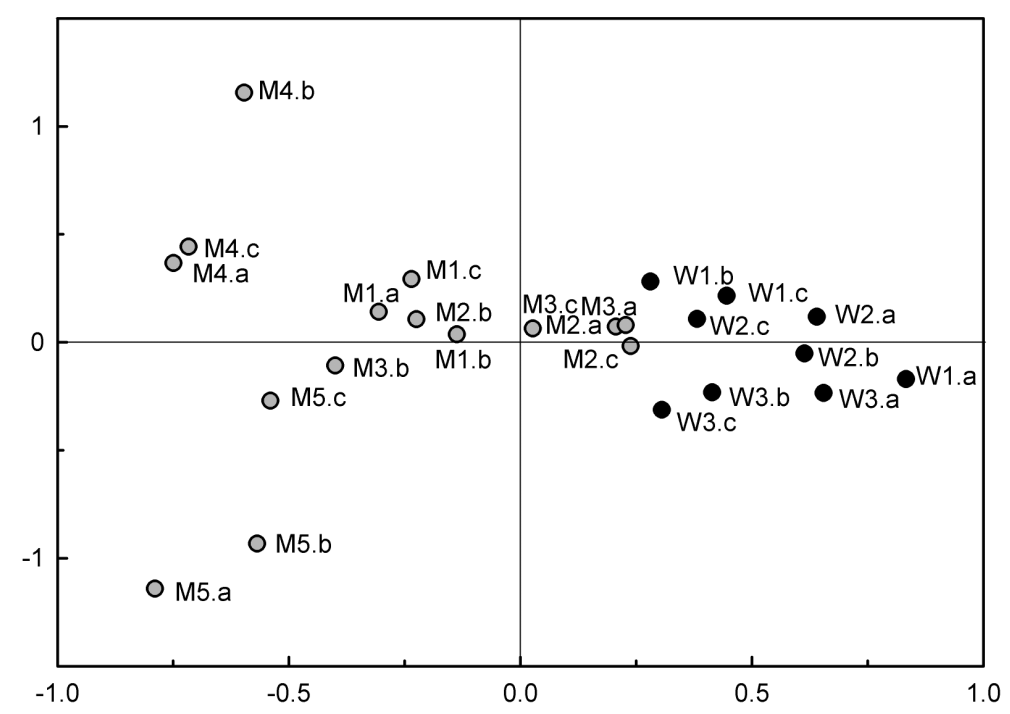

Fig. 2. Principal component analysis of sites in Mangemangeroa (M) and Waikopua (W) estuary based on plant architecture and growth rates 
seedling and pnuematophore variables. Principle component analysis was used to show how plant architecture differed from one site to another. Redundancy analysis was used to determine the relationship between environmental factors and the changes in mangrove architecture observed across the sites (CANOCO; Ter Braak 1986, 1987). Environmental factors used were (1) distance to the mouth of each estuary as a surrogate for salinity and exposure, (2) distance to the channel, (3) sedimentation rate, and (4) sediment characteristics such as grain size and chemistry. Analysis of variance was used to determine whether there were differences in photosynthetic stress $\left(F_{\mathrm{v}} / F_{\mathrm{m}}\right)$ between sites.

Relationships between macrofaunal community structure and the environmental variables were identified using canonical correspondence analysis using CANOCO (Ter Braak 1986, 1987). We also calculated similarity percentages (SIMPER; Warwick et al. 1991) based on Bray-Curtis similarities calculated from the raw data to establish species habitat affinity for existing macrobenthic distributions. From these ordinations, we were able to determine the relationships between groups of species with preferences for particular sites/habitats. Changes in macrofaunal abundance as a function of distance were analysed using regression analysis.

\section{RESULTS}

\section{Mangrove plant measurements}

Statistical analysis was conducted on all physical plant architecture variables including plant number, height, diameter, density and percentage growth for tree, sapling, seedling and pnuematophore data, where the first 4 principal component axes accounted for $97.4 \%$ of the variation in the plant site data. Plant architecture changed along a sedimentation gradient from the landward sites in the upper estuary (M5) to sites prograding seaward out onto intertidal sandflat habitats (W1) (Fig. 2). Furthermore, the PCA indicates that sites within Mangemangeroa estuary differed from the Waikopua mangroves. The upper landward sites in Mangemangeroa estuary had larger tree heights and diameters, higher seedling and pneumatophore numbers and growth rates, and higher pneumatophore death rates than sites moving down the estuary or in Waikopua (Tables 1 \& 2). However, there was also separation on the 2nd axis, where
Table 1. Eigen vectors for variables used in principal component analysis (PCA) of site data based on plant architecture, indicating the strengths of the correlations between variables and the principal components

\begin{tabular}{|lrr|}
\hline Variable & PC 1 & PC 2 \\
\hline Tree diameter growth & -0.287 & 0.766 \\
Tree diameter & -0.754 & -0.370 \\
Tree height & -1.821 & -0.717 \\
Sapling diameter growth & -0.731 & 1.467 \\
Sapling diameter & -0.278 & 1.941 \\
Sapling height growth & -1.008 & 0.686 \\
Sapling height & -1.503 & 0.902 \\
Sapling shoot growth & 0.205 & 0.641 \\
Pneumataphore death & -0.757 & -1.540 \\
Pneumataphore growth & -0.332 & -0.148 \\
Pneumataphore density & -1.129 & -0.322 \\
Seedling death & -1.403 & -0.833 \\
Seedling growth & -0.017 & 1.344 \\
Seedling density & -1.472 & 0.381 \\
\hline
\end{tabular}

taller and larger saplings with higher sapling growth rates were found at Site M4 (Table 1). Site M5 was separated on the 2nd axis by increased pneumatophore densities and increased pneumatophore and seedling death rates, suggesting a potential negative effect of elevated sedimentation rates. Redundancy analysis using forward selection indicated that sedimentation rate and fine sediment could explain $45 \%$ of the variance in the plant architecture data $(p=0.0080)$.

Principal component analysis of growth rate variables alone indicated that $95 \%$ of the variance was explained by the first 4 axes. Redundancy analysis based on forward selection suggests that growth rates were significantly related to organic matter $(0.0440)$ and log distance up the estuary (0.0320) with these 2 variables explaining $53 \%$ of the variation in growth rates.

The highest values of $F_{\mathrm{v}} / F_{\mathrm{m}}$ during full sunlight were measured at the upper landward estuary sites, M5 and

Table 2. Tree height, number of pneumatophores and total number of new seedlings, recorded over the monitoring period, and photosynthetic responses $\left(F_{\mathrm{v}} / F_{\mathrm{m}}\right)$ at each site. Means $( \pm \mathrm{SD})$ are shown

\begin{tabular}{|lcccc|}
\hline Site & $\begin{array}{c}\text { Average tree } \\
\text { height }(\mathrm{m})\end{array}$ & $\begin{array}{c}\text { Average no. of } \\
\text { pneumatophores }\end{array}$ & $\begin{array}{c}\text { Total no. of } \\
\text { new seedlings }\end{array}$ & $\begin{array}{c}F_{\mathrm{v}} / F_{\mathrm{m}} \\
(\mathrm{n}=10)\end{array}$ \\
\hline W1 & $1.07(0.18)$ & $19.64(8.85)$ & $1.00(1.45)$ & $0.691(0.03)$ \\
W2 & $0.90(0.11)$ & $27.23(6.92)$ & $1.95(0.84)$ & $0.662(0.08)$ \\
W3 & $1.22(0.26)$ & $21.50(6.11)$ & $3.09(2.58)$ & $0.673(0.06)$ \\
M1 & $1.81(0.18)$ & $30.16(11.04)$ & $5.09(3.06)$ & $0.695(0.05)$ \\
M2 & $1.64(0.19)$ & $43.33(10.32)$ & $3.05(1.36)$ & $0.688(0.09)$ \\
M3 & $0.98(0.15)$ & $65.55(21.97)$ & $3.38(2.26)$ & $0.745(0.02)$ \\
M4 & $1.63(0.09)$ & $42.77(7.19)$ & $7.85(4.47)$ & $0.696(0.02)$ \\
M5 & $2.32(0.13)$ & $48.07(13.57)$ & $4.15(2.29)$ & $0.757(0.01)$ \\
& & & & \\
\hline
\end{tabular}



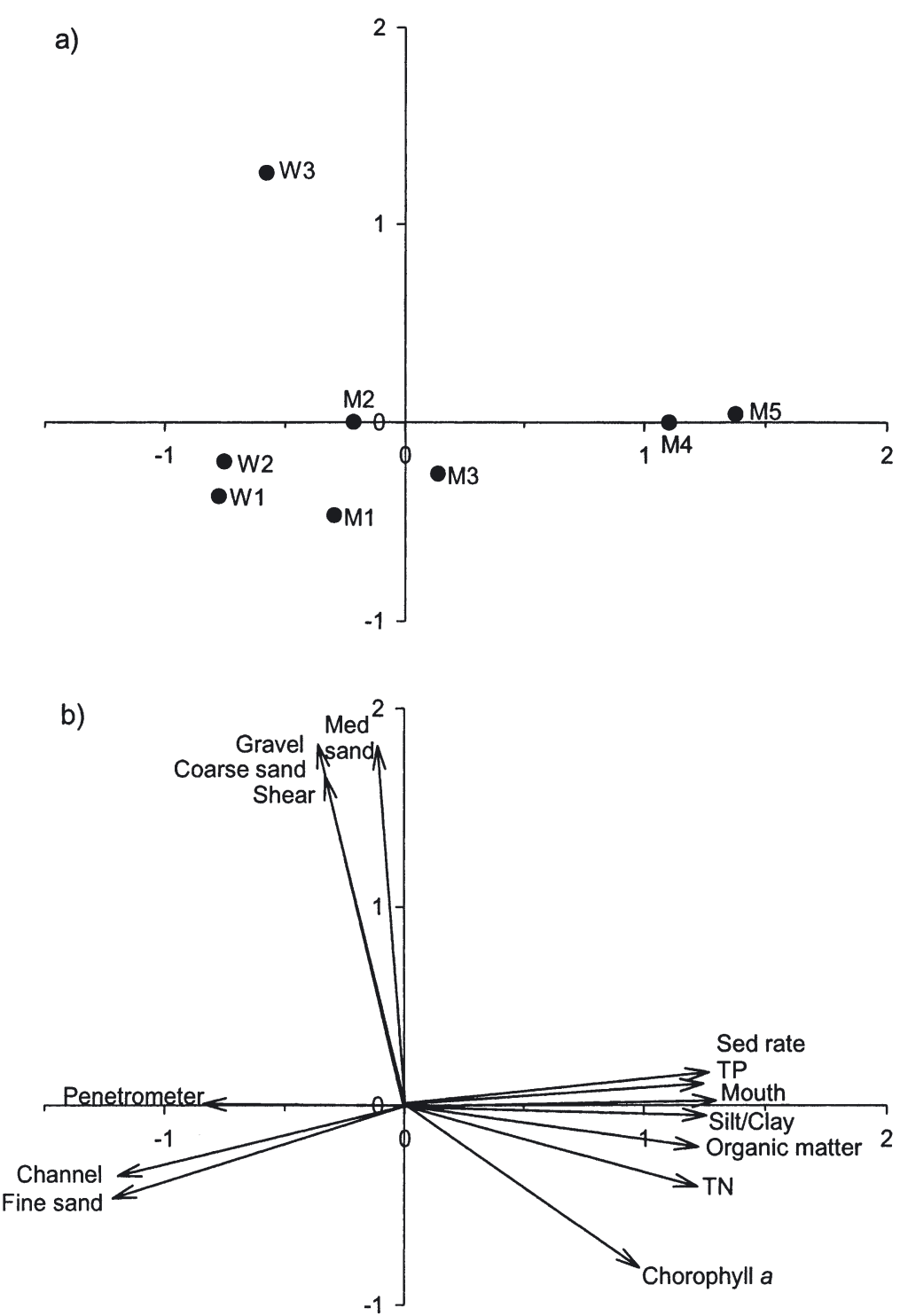

Fig. 3. Canonical correspondence analysis of sampling sites and environmental variables using plant data where (a) indicates sampling site positions and (b) indicates environmental variables. Sed rate: sedimentation rate
M3 (Table 2), where average $F_{\mathrm{v}} / F_{\mathrm{m}}$ after 15 min in the dark was close to the dawn maximum of 0.77 measured for leaves from both Mangemangeroa and Waikopua. Significant differences between $F_{\mathrm{v}} / F_{\mathrm{m}}$ levels were recorded between the 2 estuaries $(\mathrm{p}=$ 0.004). $F_{\mathrm{v}} / F_{\mathrm{m}}$ tended to be higher for leaves on mangrove plants in Mangemangeroa than in Waikopua estuary, suggesting a higher degree of photosynthetic stress in Waikopua mangroves.

\section{Environmental differences across sites}

The upper landward sites in Mangemangeroa estuary also differed from Waikopua sites based on environmental variables such as sediment type, organic content and sedimentation rate; where the first 4 axes of the analysis accounted for $95.5 \%$ of the variation in the environmental site data (Fig. 3). Surficial sediment hardness increased from Site M5 to Site M1 moving seaward at Mangemangeroa, and sediments at all sites in Waikopua (which are near the bottom of this estuary) were much harder and more cohesive (Table 3). The softer sediments in the upper landward sites of the estuary were more organic, with a higher content of VOM, chl $a$ and nutrients (TN and TP) (Table 3). Softer sediments had much higher silt clay contents $(83 \%$ at M5 decreasing to $22 \%$ at M1) (Table 4). There was also a trend for salinity to increase from the upper sites in the estuary Site M5 (30\%) to Site W1 (42.3\%o) at the seaward mouth of Waikopua (Table 3). Sites W1 and W2 experienced

Table 3. Salinity, sediment hardness (penetrometer), cohesiveness (shear vane), organic content, chlorophyll a (chl a), and total phosphorus (TP) and nitrogen (TN) content of the surficial sediments by site (mean \pm SD). Mean values are averages of the data collected every month over the 7 mo monitoring period

\begin{tabular}{|c|c|c|c|c|c|c|c|}
\hline Site & $\begin{array}{l}\text { Salinity } \\
(\%)\end{array}$ & $\begin{array}{l}\text { Sediment hard- } \\
\text { ness }\left(\mathrm{kg} \mathrm{cm}^{-2}\right)\end{array}$ & $\begin{array}{l}\text { Sediment cohesive- } \\
\text { ness }\left(\mathrm{kg} \mathrm{cm}^{-2}\right)\end{array}$ & $\begin{array}{c}\text { Organic } \\
\text { content (\%) }\end{array}$ & $\begin{array}{c}\text { Chl } a \\
\left(\mu g^{-1}\right)\end{array}$ & $\begin{array}{c}\text { TP } \\
\left(\mathrm{mg}[\mathrm{kg} \text { dry } w t]^{-1}\right)\end{array}$ & $\begin{array}{c}\text { TN } \\
\left(\mathrm{mg}[\mathrm{kg} d r y ~ w t]^{-1}\right)\end{array}$ \\
\hline W1 & $42.3(4.6)$ & $3.43(1.8)$ & $2.68(0.7)$ & $1.17(0.3)$ & $6.53(1.9)$ & $185.0(36.8)$ & $0.04(0.00)$ \\
\hline W2 & $39.6(1.5)$ & $4.08(0.7)$ & $3.17(1.8)$ & $1.09(0.2)$ & $8.56(2.6)$ & $160.5(7.7)$ & $0.04(0.00)$ \\
\hline W3 & $37.0(4.3)$ & $2.37(0.9)$ & $3.05(2.2)$ & $1.32(0.2)$ & $6.64(0.9)$ & $250.0(43.8)$ & $0.04(0.00)$ \\
\hline M1 & $35.6(0.6)$ & $0.89(0.4)$ & $4.57(1.6)$ & $2.87(1.3)$ & $11.3(5.2)$ & $283.5(24.7)$ & $0.09(0.02)$ \\
\hline M2 & $33.0(0.0)$ & $0.59(0.4)$ & $3.03(1.4)$ & $1.82(0.3)$ & $5.99(3.4)$ & 257.5 (16.3) & $0.06(0.01)$ \\
\hline M3 & $33.3(0.6)$ & $0.24(0.2)$ & $2.30(0.9)$ & $2.80(0.8)$ & $14.01(4.4)$ & $280.0(12.7)$ & $0.07(0.01)$ \\
\hline M4 & $30.0(0.0)$ & $0.29(0.2)$ & $3.10(0.5)$ & $6.56(0.9)$ & $13.74(5.1)$ & $615.0(80.6)$ & $0.21(0.01)$ \\
\hline M5 & $30.0(0.0)$ & $0.41(0.2)$ & $3.46(0.9)$ & $7.29(3.0)$ & $14.78(5.1)$ & $633.0(120.2)$ & $0.21(0.00)$ \\
\hline
\end{tabular}


Table 4. Volumetric composition (\%) of the surficial sediments by site (mean \pm SD). Mean values are averages of the data collected every month over the 7 mo monitoring period

\begin{tabular}{|lccccc|}
\hline Site & $\begin{array}{c}\text { Silt/clay }(\%) \\
(<62.5 \mu \mathrm{m})\end{array}$ & $\begin{array}{c}\text { Fine sand }(\%) \\
(62.5 \text { to } 250 \mu \mathrm{m})\end{array}$ & $\begin{array}{c}\text { Medium sand (\%) } \\
(250 \text { to } 500 \mu \mathrm{m})\end{array}$ & $\begin{array}{c}\text { Coarse sand }(\%) \\
(500 \text { to } 2000 \mu \mathrm{m})\end{array}$ & $\begin{array}{c}\text { Gravel }(\%) \\
(>2000 \mu \mathrm{m})\end{array}$ \\
\hline W1 & $15.32(8.51)$ & $82.75(12.08)$ & $1.32(2.51)$ & $0.45(0.76)$ & $0.05(0.05)$ \\
W2 & $18.50(2.06)$ & $81.34(2.04)$ & $0.12(0.06)$ & $5.51(2.83)$ & $0.14(0.34)$ \\
W3 & $16.49(7.33)$ & $61.86(18.06)$ & $8.01(3.98)$ & $1.01(0.72)$ & $8.12(9.71)$ \\
M1 & $22.11(7.96)$ & $72.61(5.36)$ & $3.17(2.97)$ & $0.39(0.14)$ & $1.09(2.06)$ \\
M2 & $25.63(2.49)$ & $70.92(2.39)$ & $2.71(0.57)$ & $0.59(0.66)$ & $0.33(0.73)$ \\
M3 & $28.13(12.63)$ & $69.54(11.66)$ & $1.58(0.43)$ & $0.14(0.27)$ & $0.15(0.32)$ \\
M4 & $87.23(3.47)$ & $12.25(3.40)$ & $0.36(0.20)$ & $0.16)$ & $0.01(0.02)$ \\
M5 & $82.95(5.82)$ & $15.31(4.22)$ & $1.63(1.89)$ & & $0.02(0.04)$ \\
\hline
\end{tabular}

lower net accumulation of sediments and were sandier with corresponding lower particulate organic matter, \% silt/clay and chl a levels.

\section{Sedimentation rates}

The dry weights, organic content and grain size of the sediment collected in the bedload traps over the $7 \mathrm{mo}$ monitoring period and the sedimentation rate as estimated from radioisotopic analysis are given in Table 5. Sedimentation measured over decadal time scales indicated increased sedimentation rates in the upper landward reaches of both estuaries (M5, M4 and W3) which are more sheltered as expected. However, sites at the seaward mouths of the estuary (M1 and W1) experienced no net accumulation over time due to resuspension from wind-wave disturbance. Since 1953, $1 \mathrm{~m}$ of sediment has been deposited in the upper estuary of Mangemangeroa, while less than $0.1 \mathrm{~m}$ has been deposited in the lower estuary. The high levels of sedimentation in the Mangemangeroa estuary are due to its long residence time, low wave energy climate and low tidal flushing. The same pattern of sedimentation was found at sites in the Waikopua estuary, although rates were lower than those in Mangemangeroa as the Waikopua sites were further down the estuary and more exposed to wave action which reduces long-term sediment accumulation.

Analysis of the sediment cores taken at Waikopua running seaward onto the intertidal sandflats and landward into the older mangrove stands beyond the monitored sites show a gradient in the mud and zinc composition of the sediment between upstream and downstream sites $\left(\mathrm{Zn}=0.62 \mathrm{x}+3.61 ; \mathrm{r}^{2}=0.65\right.$; where $x=$ sediment mud content), with higher percentage volumes of mud in the sediment at the uppermost sites.
Zinc levels associated with the mud fraction of cores from within the mangrove stand in Waikopua were 2 to 5 times the background level for mud/sand flats in this estuary and other estuaries in the region. The high zinc content indicates that the mud has been deposited after urban development of catchments discharging into Whitford Bay. The zinc data reflects the fact that long-term accumulation of the sediment mud fraction occurs in low energy depositional environments (e.g. mangrove) rather than on the intertidal flats. The most likely causal mechanisms for the low mud content of intertidal flat sediments are selective wave re-suspension of small particles and the particles lower settling speeds, which favour deposition in low energy environments.

The sedimentation rates collected in the bedload traps over the 7 mo monitoring period (Table 5) also suggest that sites in the upper estuary experience high net accumulation of fine muds (255 $\mathrm{g}$ of sediment comprised of $97 \%$ silt/clay at Site M5). Interestingly, sites at the entrances to both estuaries also showed high net accumulation. However, analysis of particle size indicates that these sediments were comprised of a higher proportion of fine sands (e.g. $277 \mathrm{~g}$ of total sediment col-

Table 5. Net sedimentation rate at each site (as measured over decadal timescales) and composition of sediment collected in the bedload traps over the 7 mo monitoring period. Bedload data include total sediment weight $(\mathrm{g})$, organic matter content of the sediments collected (\%) and grain size composition (\%)

\begin{tabular}{|ccrcccc|}
\hline Site & $\begin{array}{c}\text { Net sedimen- } \\
\text { tation rate } \\
\left(\mathrm{mm} \mathrm{yr}^{-1}\right)\end{array}$ & $\begin{array}{c}\text { weight } \\
(\mathrm{g})\end{array}$ & $\begin{array}{c}\text { Organic } \\
\text { matter } \\
(\%)\end{array}$ & $\begin{array}{c}\text { Silt/clay } \\
(\%) \\
(<62.5 \mu \mathrm{m})\end{array}$ & $\begin{array}{c}\text { Fine sand } \\
(\%)(62.5 \text { to } \\
250 \mu \mathrm{m})\end{array}$ & $\begin{array}{c}\text { Sand }(\%) \\
(250 \text { to } \\
2000 \mu \mathrm{m})\end{array}$ \\
\hline W1 & 0.0 & 367.50 & 2.80 & 55.24 & 43.50 & 1.27 \\
W2 & 0.0 & 56.58 & 4.85 & 52.39 & 47.06 & 0.55 \\
W3 & 2.6 & 22.05 & 4.49 & 83.81 & 14.72 & 1.47 \\
M1 & 0.0 & 277.22 & 7.58 & 49.86 & 47.56 & 2.57 \\
M2 & 1.1 & 102.53 & 4.66 & 98.68 & 0.00 & 1.33 \\
M3 & 1.1 & 99.55 & 4.64 & 99.82 & 0.00 & 0.18 \\
M4 & 14.8 & 59.77 & 3.76 & 96.97 & 3.03 & 0.00 \\
M5 & 23.4 & 255.83 & 5.86 & 97.37 & 0.00 & 2.62 \\
& & & & & & \\
\hline
\end{tabular}


lected, comprised of $49 \%$ silt/clay and $47 \%$ fine sands at Site M1). The higher percentage of fine sand suggests deposition of marine sediments following resuspension by wind-waves rather than a predominance of terrigenous sediment inputs which occur at the upper landward estuary sites.

\section{Macrobenthic community composition}

To identify relationships between benthic community composition, mangrove plant architecture and environmental parameters data were analysed using canonical correspondence analysis (Fig. 4). Again,

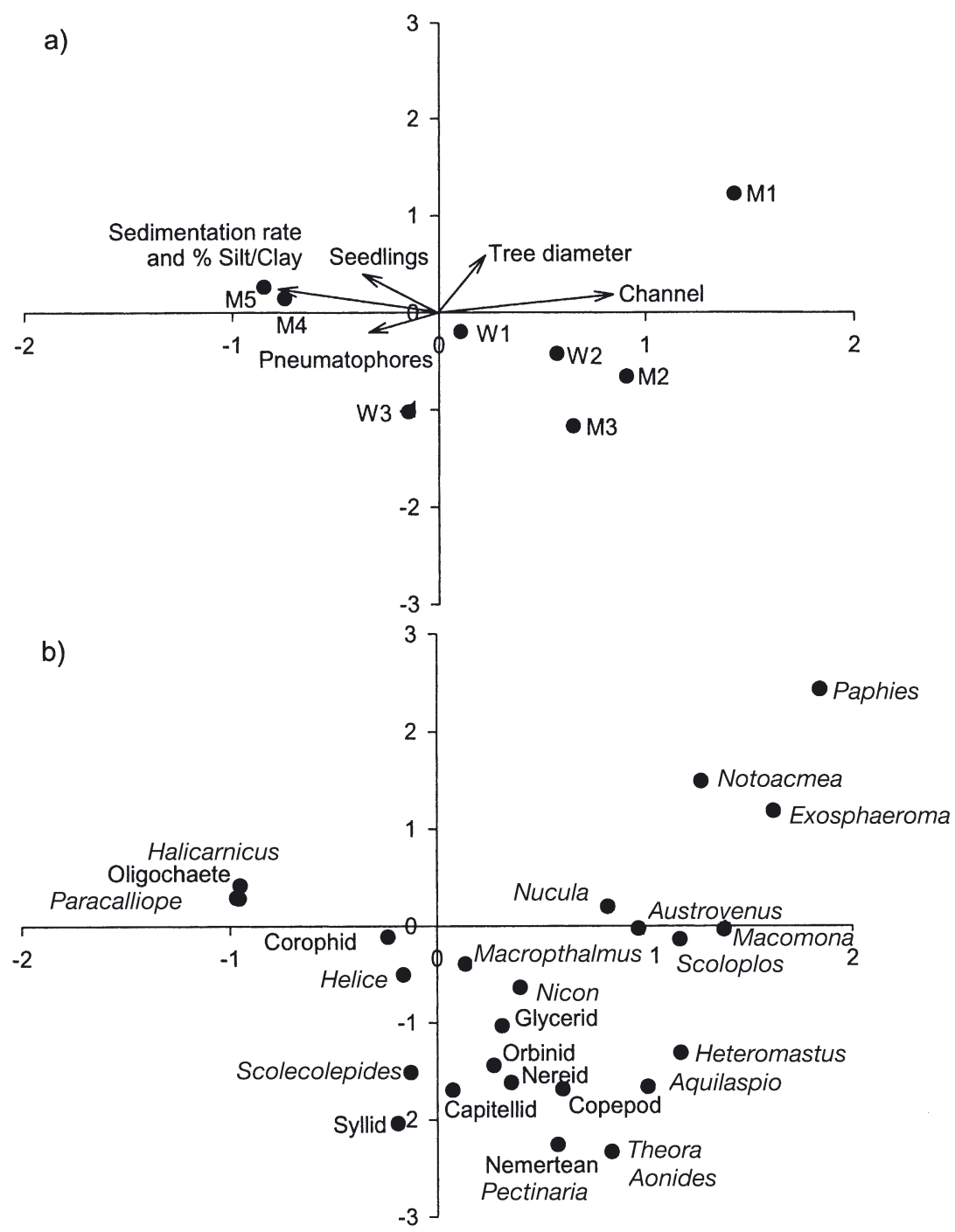

Fig. 4. Canonical correspondence analysis of the macrofaunal community composition at the different mangrove sites in relation to changing environmental conditions where (a) indicates environmental variables and sampling site positions and (b) indicates positions of genera and faunal groups sites in the ordination were grouped down a sedimentation gradient from the landward sites in the estuary with high sedimentation rates and silt/clay contents (M5 and M4) to seaward sites at the entrances to the estuaries (M1). The environmental variables that best explained benthic community composition site differences included silt/clay content of the sediment, distance to the channel and a number of plant architecture variables (tree height and diameter, number of seedlings, and number of pneumatophores).

Benthic community composition at the upper sites (M5/M4) were dominated by the amphipod Paracolliopidae sp., oligochaetes, the crabs Halicarcinus whitei and Helice crassa, and corophids. Because the corer may be inadequate at estimating the density of large mobile macrofauna such as crabs, burrow density from photographic quadrats were also recorded. The number of burrows estimated in this study suggests higher crab abundance at the Mangemangeroa sites than the Waikopua sites, and slight increases in density at the upper landward sites (M3, M4 and M5), supporting the higher numbers recorded from the core data. The benthic community composition at the seaward sites in the estuary closest to the intertidal sandflats (M1) were differentiated by several bivalve species Paphies australis, Macomona liliana, Austrovenus stutchburyi and Nucula hartvigiana, the gastropod Notoacmea helmsii and the isopod Exosphaeroma chilensis.

Comparison of functional differences between these mangrove benthic communities and other habitat types was possible due to a large survey that was conducted in November 2000, $1 \mathrm{wk}$ prior to our sampling in December. The exact same collection and processing methods were used. This included comparisons of both nonvegetated mudflat communities in the upper estuary adjacent to the mangrove stands as well as non-vegetated intertidal sandflat communities from the Whitford Embayment. Subsurface deposit feeders dominated the benthic community composition in the mangrove habitats (Fig. 5). Primarily a high proportion of polychaetes $($ Dec $00=59 \%$; Sep $01=64 \%$; Mar $02=$ $45 \%$ ) dominated these mangrove sites. The burrowing crab Helice crassa and amphipods were also recorded at these sites that were not abundant on the nonvegetated sandflat sites (Table 6). A high 


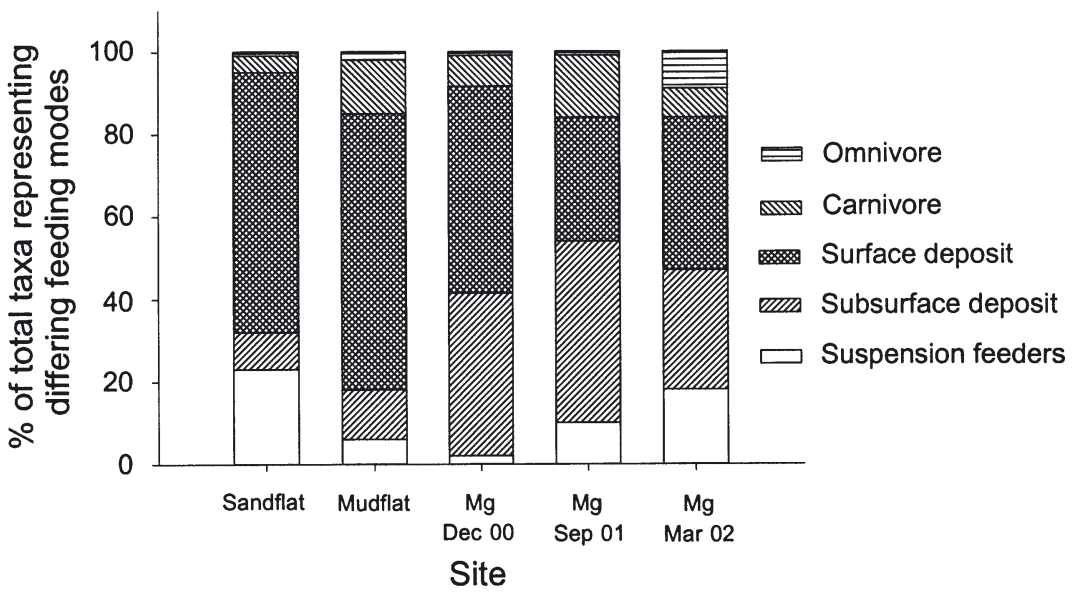

Fig. 5. Relative percentage of varying benthic feeding modes in the mangrove $(\mathrm{Mg})$ habitats recorded over time versus the mudflat and intertidal sandflat habitats. Sandflat and Mudflat data were collected by A. Norkko, S. Talman, J. Ellis, P. Nicholls, S. Thrush (unpubl.)

proportion of these subsurface feeders were head-down deposit-feeding polychaetes (Fig. 6), including Scoloplos cylindrifer, Heteromastus filiformis, capitellids and oligochaetes. The benthic community composition of the mudflat sites adjacent to the mangrove habitats was dominated by amphipods, the crab Helice crassa and polychaetes (Fig. 6, Table 6). The top 5 dominant taxa as determined via SIMPER accounted for $73 \%$ of the variability within the habitat. This high explanatory power of only 5 taxa demonstrates low macrobenthic diversity in these upper muddy estuarine habitats. Four species of amphipods were recorded; however, 1 species of amphipod, Paracorophium excavatum, accounted for $53 \%$ of the total abundance of all macrofauna recorded. This species is a surface deposit feeder, and hence also explains the predominance of this feeding mode in Fig. 5. Higher percentages of surface deposit feeders and suspension feeders were recorded from the non-vegetated sandflat sites taken in the Whitford Embayment (Fig. 5). These intertidal sandflat sites were dominated by a higher percentage of bivalves (Fig. 6), including Macomona liliana, Austrovenus stutchburyi and Nucula hartvigiana (Table 6). The lower explanatory power of the 5 most dominant taxa $(48 \%)$ demonstrates the comparatively high macrobenthic diversity of these sandflats as many other spe- cies are required to more accurately explain the within site community variability.

The diversity and abundance of benthic communities in the mangrove sites (average diversity $=8.13$ ) was lower than on intertidal sandflats (average diversity $=18.1$ ) . However, the lower diversity and abundance of animals was consistent for both vegetated mangrove habitats (average diversity $=8.13$ ) and unvegetated tidal mudflats adjacent to mangrove areas (average diversity $=9.1$ ). At a finer scale, within the mangrove sites, no trends in diversity were apparent. Abundance appeared to increase at the upper estuary sites within Mangemangeroa estuary, but this relationship was not significant $\left(\mathrm{r}^{2}=0.113\right)$ due to considerable seasonal variability in benthic patterns (Table 7).

Table 6. Rankings of the 5 most dominant macrofaunal taxa in each habitat category, as determined from similarity percentages analysis

\begin{tabular}{|c|c|c|c|}
\hline Habitat and dominant taxa & Faunal group & $\%$ explained & $\begin{array}{c}\text { Cumulative \% } \\
\text { explained }\end{array}$ \\
\hline \multicolumn{4}{|l|}{ Sandflat } \\
\hline Macomona liliana & Bivalve & 13.0 & 13.0 \\
\hline Aquilaspio aucklandica & Polychaete & 10.6 & 23.6 \\
\hline Austrovenus stutchburyi & Bivalve & 9.5 & 33.1 \\
\hline Nucula hartvigiana & Bivalve & 9.3 & 42.4 \\
\hline Colurostylis lemurum & Cumacean & 6.0 & 48.4 \\
\hline \multicolumn{4}{|l|}{ Mudflat } \\
\hline Paracorophium excavatum & Amphipod & 26.5 & 26.5 \\
\hline Helice crassa & Decapod & 22.3 & 48.8 \\
\hline Aquilaspio aucklandica & Polychaete & 12.0 & 60.8 \\
\hline Nereid & Polychaete & 6.8 & 67.6 \\
\hline Heteromastus filiformis & Polychaete & 5.6 & 73.2 \\
\hline \multicolumn{4}{|l|}{ Mangrove (Dec 00) } \\
\hline Scoloplos cylindrifer & Polychaete & 25.3 & 25.3 \\
\hline Scolecolepides sp. & Polychaete & 24.6 & 49.9 \\
\hline Helice crassa & Decapod & 20.6 & 70.5 \\
\hline Nicon sp. & Polychaete & 7.3 & 77.8 \\
\hline Aquilaspio aucklandica & Polychaete & 4.1 & 81.9 \\
\hline \multicolumn{4}{|l|}{ Mangrove (Sep 01) } \\
\hline Helice crassa & Decapod & 30.0 & 30.0 \\
\hline Scolecolepides sp. & Polychaete & 26.1 & 56.1 \\
\hline Scoloplos cylindrifer & Polychaete & 9.5 & 65.6 \\
\hline Paracollipidiae sp. & Amphipod & 9.0 & 74.6 \\
\hline Oligochaete & Oligochaete & 7.5 & 82.1 \\
\hline \multicolumn{4}{|l|}{ Mangrove (Mar 02) } \\
\hline Helice crassa & Decapod & 53.2 & 53.2 \\
\hline Oligochaete & Oligochaete & 16.7 & 69.9 \\
\hline Scolecolepides sp. & Polychaete & 8.2 & 78.1 \\
\hline Scoloplos cylindrifer & Polychaete & 7.4 & 85.5 \\
\hline Corophium & Amphipod & 6.6 & 92.1 \\
\hline
\end{tabular}




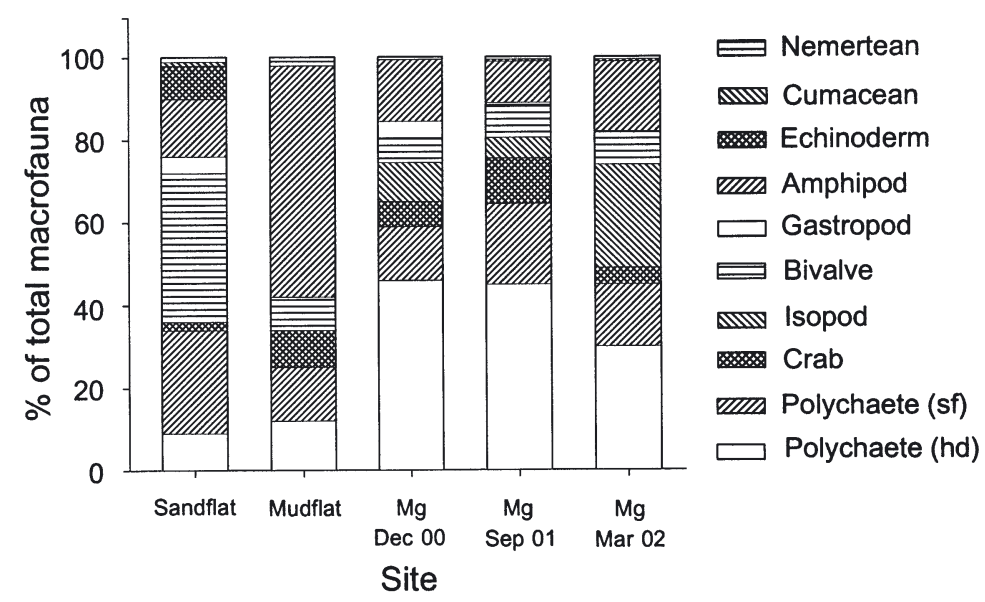

Fig. 6. Relative percentage of varying benthic faunal groups in the mangrove $(\mathrm{Mg})$ habitats recorded over time versus the mudflat and intertidal sandflat habitats. hd: head-down feeder; sf: suspension feeder. Sandflat and Mudflat data were collected by A. Norkko, S. Talman, J. Ellis, P. Nicholls, S. Thrush (unpubl.)

\section{DISCUSSION}

We designed our study to determine the effects of high sedimentation rates on mangrove plant communities and associated benthic community composition. Our study was conducted at an estuary that is experiencing high rates of sedimentation (as high as $23 \mathrm{~mm}$ $\mathrm{yr}^{-1}$ ) with associated increases in mangrove plants over large areas of the estuary. We recorded clear differences in both plant and benthic communities along a gradient of decreasing sedimentation. Mangrove plant architecture and health were linked to high mud content of the sediment and elevated sedimentation patterns. Mangrove plants at the landward sites, characterised by a high percentage of mud and relatively high TP, TN and organic content, were taller, had higher numbers of pneumatophores and had the highest numbers of new seedlings over the monitoring period. Further, $F_{\mathrm{v}} / F_{\mathrm{m}}$ indicated that mangrove plants were less stressed at these upper estuarine sites.

However, while plant health was linked to increasing sedimentation rates, benthic macrofaunal diversity and abundance within these habitats was lower than expected and clear functional differences were found between habitats with differing sedimentation patterns. When investigating benthic community patterns within mangrove habitats alone, apparent trends in increased densities of benthic animals were recorded up the estuary. However, at a larger scale when comparing these upper tidal areas with as- sociated intertidal sandflat habitats, the diversity and density of benthic macrofaunal communities was lower for both mangrove habitats and adjacent intertidal mudflats. These results suggest that the lower macrofaunal diversity in these upper landward areas is not a factor of the mangrove plants themselves, but rather a response to the increased silt/clay from sedimentation that occurs in these upper tidal areas.

The pattern of increased mangrove health and larger tree size in relation to high mud content of the sediment and elevated sedimentation patterns we recorded is consistent with other published studies. In a comparison of mangrove growth across a number of New Zealand estuaries, tree growth declined as the mud content of the sediment decreased (Dingwall 1984, de Lange \& de Lange 1994). Further, plants that grew in sediments containing less than $50 \%$ mud were often stunted. Mangrove plant form has also been correlated with sedimentation rate, where taller, single-stemmed Avicennia stands grow on newly deposited sediment, while smaller multistemmed trees were found on older sediments (Clarke 1993). High amounts of sedimentation, however, can have a deleterious effect on mangrove plants, even causing the death of trees if the pneumatophores become smothered (Ellison 1998).

While the plant responses documented in this study are consistent with other published studies, the benthic macrofaunal responses recorded were lower than expected. Evidence suggests that the lower diversity and abundance of macrobenthic assemblages recorded was associated with the high sedimentation rates that are occurring in this estuary. Further functional shifts towards a predominance of deposit feeders, especially high numbers of head-down depositfeeding polychaetes and oligochaetes, occurred in the
Table 7. Number of species and density of macrobenthic animals over time at each site. Means $( \pm \mathrm{SD})$ are shown

\begin{tabular}{|c|c|c|c|c|c|c|}
\hline \multirow{2}{*}{ Site } & \multicolumn{2}{|c|}{$\perp_{\text {Dec } 00}$} & \multicolumn{2}{|c|}{ Sep 01} & \multicolumn{2}{|c|}{ Mar 02} \\
\hline & No. of taxa & No. of ind. & No. of taxa & No. of ind. & No. of taxa & No. of ind. \\
\hline W1 & $4.3(1.5)$ & & & $11.3(5.5)$ & $1.7(1.2)$ & $10.0(13.9)$ \\
\hline W2 & 1.0 & $2.3 i$ & & 6) & .6) & $0.6)$ \\
\hline W3 & $3.3(3.2)$ & $10.6(1$ & 5) & 7.0 & .6) & $0.7(0.6)$ \\
\hline M1 & $9.0(4.4)$ & 17. & & 31.7 & & $26.3(17.0)$ \\
\hline M2 & $5.6(2.8)$ & 14.9 & & & & $8.7(4.2)$ \\
\hline M3 & $10.3(2.5)$ & $31.0(12.3)$ & $7.7(3$. & $24.7(15.2)$ & $4.3(2.5)$ & $21.0(24.8)$ \\
\hline M4 & $8.3(2.5)$ & $73.3(59.3)$ & $3.3(1.5)$ & $34.3(23.9)$ & $3.0(3.0)$ & $6.3(5.5)$ \\
\hline M5 & $7.3(1.5)$ & $38.0(17.3)$ & $4.7(1.5)$ & $75.0(47.8)$ & $4.0(1.4)$ & $16.0(5.7)$ \\
\hline
\end{tabular}


upper estuarine habitats which differed from the intertidal sandflat communities where suspension feeders and larger numbers of bivalve species were recorded. Results of studies comparing vegetated (such as mangrove and seagrass areas) versus unvegetated habitats often report higher diversity of benthic communities in these more complex vegetated habitats (Lewis 1984, Edgar 1990). However, more recent studies investigating the relationship between mangrove detritus and meiofaunal density in other areas suggest that the high tannin content and the refractory nature of most mangrove litter may offer little positive impact on benthic faunal assemblages (Alongi 1987, 1990, Alongi et al. 1989). Alongi \& Christoffersen (1992) investigated the influence of outwelled mangrove detritus on macroand meiofaunal densities and reported total infaunal density relating negatively with the percentage of clay and mangrove leaf litter content as well as a predominant taxa of small surface-dwelling polychaetes and amphipods. In a study that specifically investigated changes in benthic communities along sand to mud gradients for unvegetated intertidal flats in New Zealand estuaries, decreases in diversity were also recorded with increases in mud content, and interestingly a decrease in total density with increasing mud content was recorded (Thrush et al. 2003b). Hence, there is evidence to suggest that the lower diversity and abundance recorded in this study is associated with the high sedimentation rates that are occurring in this estuary.

In general, our findings are consistent with those of other field studies that have investigated effects of sedimentation on benthic community composition. For example, gradual sedimentation of Kane'ohe Bay (Hawaii) resulted in a loss of suspension-feeding populations and a macrobenthic community with low diversity, small mean body size, low biomass and relatively low productivity (Smith \& Kukert 1996). A further study demonstrated highly deleterious effects of catastrophic terrigenous clay deposition on estuarine macrobenthic communities both in terms of mass mortality and slow recovery rates, and implications for longer-term changes in community structure due to alterations of the habitat and resource availability (Norkko et al. 2002).

Our results support this growing body of work that demonstrates that high rates of sedimentation have serious negative implications for the functioning and diversity of estuarine benthic systems. Because these upper tidal habitats act as sedimentary areas for terrigenous silt/clay particles, they are experiencing particularly high rates of sedimentation. While this provides an important role in reducing turbidity to other parts of the estuary, the very high rates of sedimentation are influencing the overall diversity in these upper estuarine areas, both on intertidal mudflats and within mangrove stands. There is a need to investigate the meiofaunal community composition in these impacted mangrove systems to determine whether they are also experiencing similar decreases in diversity. Soft-sediment community composition in more sandy New Zealand mangrove estuaries is also an area requiring further research in order to determine the biodiversity and functional and structural roles of these systems in less impacted environments.

Acknowledgements. We wish to thank Ron Ovenden for help with processing the sedimentation cores. Comments by Anne-Maree Schwarz and Andrew Swales greatly helped to improve the manuscript. This research was funded by the Auckland Regional Council and the New Zealand Foundation for Research Science and Technology (FRST-C01X0024).

\section{LITERATURE CITED}

Alongi DM (1987) The influence of mangrove derived tannins on intertidal meiobenthos in tropical estuaries. Oecologia 71:537-540

Alongi DM (1990) Abundances of benthic microfauna in relation to outwelling of mangrove detritus in a tropical coastal region. Mar Ecol Prog Ser 63:53-63

Alongi DM, Christoffersen P (1992) Benthic infauna and organism-sediment relations in a shallow, tropical coastal area: influence of outwelled mangrove detritus and physical disturbance. Mar Ecol Prog Ser 81:229-245

Alongi DM, Boto KG, Tirendi F (1989) Effect of exported mangrove litter on bacterial productivity and dissolved organic carbon fluxes in adjacent tropical nearshore sediments. Mar Ecol Prog Ser 56:129-140

Benoit G, Rozan TF, Patton PC, Arnold CL (1999) Trace metals and radionuclides reveal sediment sources and accumulation rates in Jordan Cove, Connecticut. Estuaries 22(1): $65-80$

Burns BR, Ogden J (1985) The demography of the temperate mangrove [Avicennia marina (Forsk.) Vierh] at its southern limit in New Zealand. Aust J Ecol 10:125-133

Butman CA, Grant WD, Stolzenbach KD (1986) Predictions of sediment trap biases in turbulent flows: a theoretical analysis based on observations from the literature. J Mar Res 44:601-644

Clarke PJ (1993) Mangrove, salt marsh and peripheral vegetation of Jervis Bay. Cunninghamia 3(1):231-254

Crisp P, Daniel L, Tortell P (1990) Mangroves in New Zealand: trees in the Tide. GP Books, Wellington

Cummings V, Thrush S, Hewitt J, Norkko A, Pickmere S (2003) Terrestrial sediment deposits on interdial sandflats: sediment characteristics as indicators of habitat suitability for recolonising macrofauna. Mar Ecol Prog Ser 253:39-54

de Lange WP, de Lange PJ (1994) An appraisal of factors controlling the latitudinal distribution of mangrove (Avicennia marina var. resinifera) in New Zealand. J Coast Res 10(3): 539-548

Dingwall PR (1984) Overcoming problems in the management of New Zealand mangrove forests. In: Teas HJ (ed) Physiology and management of mangroves. Dr W Junk Publishers, The Hague, p 97-106

Edgar G (1990) The influence of plant structure on the species richness, biomass and secondary production of macrofau- 
nal assemblages associated with Western Australian seagrass beds. J Exp Mar Biol Ecol 137:215-240

Ellis J, Cummings V, Hewitt J, Thrush S, Norkko A (2002) Determining effects of suspended sediment on condition of a suspension feeding bivalve (Atrina zelandica): results of a survey, a laboratory experiment and a field transplant experiment. J Exp Mar Biol Ecol 267:147-174

Ellison JC (1998) Impacts of sediment burial on mangroves. Mar Pollut Bull 37(8-12):420-426

Gardner WD (1980) Field assessment of sediment traps. J Mar Res 38:41-52

GESAMP (Joint Group of Experts on the Scientific Aspects of Marine Environmental Protection) (1994) Anthropogenic influences of sediment discharge to the coastal zone and environmental consequences. GESAMP report study no. 52. UNESCO, Paris

Gray JS (1997) Marine biodiversity: patterns, threats and conservation needs. Biodivers Conserv 6:153-175

Hedges JI, Lee C, Wakeham SG, Hernes PJ, Peterson ML (1993) Effects of poisons and preservatives on the fluxes and elemental compositions of sediment trap materials. J Mar Res 51:651-668

Lewis FG (1984) Distribution of macrobenthic crustaceans associated with Thalassia, Halodule and bare sand substrata. Mar Ecol Prog Ser 19:101-113

Mook DH, Hoskin CM (1982) Organic determination by ignition: caution advised. Estuar Coast Shelf Sci 15:697-699

Norkko A, Thrush SF, Hewitt JE, Cummings VJ and 5 others (2002) Smothering of estuarine sandflats by terrigenous clay: the role of wind-wave disturbance and bioturbation in site-dependent macrofaunal recovery. Mar Ecol Prog Ser 234:23-41

Olsen CR, Simpson HJ, Peng TH, Bopp RF, Trier RM (1981) Sediment mixing and accumulation rate effects on radionucleotide depth profiles in Hudson Estuary sediments. J Geophys Res 86(C11):11020-11028

Prange JA, Dennison WC (2000) Physiological responses of five seagrass species to trace metals. Mar Pollut Bull 41: 327-336

Ritchie JC, McHenry JR (1989) Application of radioactive fallout cesium- ${ }^{-137}$ for measuring soil erosion and sediment accumulation rates and patterns: a review with bibliography. Hydrology Laboratory, Agriculture Research Service, United States Department of Agriculture, Beltsville, MD

Editorial responsibility: John Gray (Contributing Editor), Oslo, Norway
Robbins JA, Edgington DN (1975) Determination of recent sedimentation rates in Lake Michigan using ${ }^{210} \mathrm{~Pb}$ and ${ }^{137}$ Cs. Geochim Cosmochim Acta 39:285-304

Saiz-Salini JI, Urkiaga-Alberdi J (1999) Faunal responses to turbidity in a man-modified Bay (Bilbao, Spain). Mar Environ Res 47:331-347

Sartory DP (1982) Spectrophotometric analysis of chlorophyll $a$ in freshwater phytoplankton. Technical report no. 115. Hydrological Research Institute, Pretoria

Schreiber U, Bilger W, Neubauer C (1994) Chlorophyll fluorescence as a non-intrusive indicator for rapid assessment of in vivo photosynthesis. In: Schulze M, Caldwell MM (eds) Ecophysiology of photosynthesis. Springer-Verlag, Berlin, p 49-70

Sheridan P (1997) Benthos of adjacent mangrove, seagrass and non-vegetated habitats in Rookery Bay, Florida, USA. Estuar Coast Shelf Sci 44(4):455-469

Smith CR, Kukert H (1996) Macrobenthic community structure, secondary production, and rates of bioturbation and sedimentation at the Kane'ohe Lagoon Floor. Pac Sci 50(2): 211-229

Ter Braak CJF (1986) Canonical correspondence analysis: a new eigenvector technique for multivariate direct gradient analysis. Ecology 67(5):1167-1179

Ter Braak CJF (1987) The analysis of vegetation-environment relationship by canonical correspondence analysis. Vegetatio 69:69-77

Thrush SF, Hewitt JE, Norkko A, Cummings VJ, Funnell GA (2003a) Catastrophic sedimentation on estuarine sandflats: recovery of macrobenthic communities is influenced by a variety of environmental factors. Ecol Appl 13: 1433-1455

Thrush SF, Hewitt JE, Norkko A, Nicholls PE, Funnell GA, Ellis JI (2003b) Habitat change in estuaries: predicting broad-scale responses of intertidal macrofauna to sediment mud content. Mar Ecol Prog Ser 263:101-112

Valette-Silver NJ (1993) The use of sediment cores to reconstruct historical trends in contamination of estuarine and coastal sediments. Estuaries 16(3B):577-588

Warwick RM, Goss-Custard JD, Kirby R, George CL, Pope ND, Rowden AA (1991) Static and dynamic environmental factors determining the community structure of estuarine macrobenthos in SW Britain: Why is the Severn Estuary different? J Appl Ecol 28:329-345

Submitted: July 15, 2003; Accepted: November 19, 2003 Proofs received from author(s): March 26, 2004 